\title{
PENGARUH MODEL PEMBELAJARAN VALUE CLARIFICATION TECHNIQUE (VCT) TIPE PERCONTOHAN TERHADAP PRESTASI BELAJAR DAN TANGGUNG JAWAB MATERI GLOBALISASI
}

\author{
Desty Ratna Permatasari \\ SD N 1 Tinggarjaya, Purwokerto, Indonesia \\ Email: destyratnapermata@gmail.com
}

\begin{abstract}
Abstract. This research aims to find out the effectiveness of Value Clarification Technique (VCT) learning model of exampling type toward learning achievement for the forth graders of SD N 1 Tinggarjaya in Civic Education Subject on the topic of Globalization. This is an experimental design with Randomized control group pretesposttest research design. The subject of the research was the student of for the Fourth Graders of SD N 1 Tinggarjaya academic year 2014/2015 consisting 32 students of class IVA as contro, class and 33 students of class IVB as experimental class. The technique of the data collection was by posttest in the form of filling short answer and statement with 10 items., while for the student's responsibility technique, it used questionnare technique. The data had been gained were then analyzed to test hyphothesis by using the formula of t test. Based on the result of the research, it was found that the application of VCT learning model exampling type affected on learning achievement for the fourth graders of SD N 1 Tinggarjaya in Civics Education Subject on the topic of Globalization.
\end{abstract}

Key Words :Value Clarification Technique (VCT), exampling type, learning achievement, Civics Education, Globalization.

\section{ABSTRAK}

Penelitian ini bertujuan untuk mengetahui keefektifan model pembelajaran Value Clarification Technique (VCT) tipe exampling terhadap prestasi belajar siswa kelas IV SD N 1 Tinggarjaya dalam Mata Pelajaran Pendidikan Kewarganegaraan pada topik Globalisasi. Ini adalah desain eksperimental dengan desain penelitian acak kelompok pretes-posttest. Subjek penelitian adalah siswa kelas IV SD N 1 Tinggarjaya tahun akademik 2014/2015 yang terdiri dari 32 siswa kelas IVA sebagai contro, kelas dan 33 siswa kelas IVB sebagai kelas eksperimen. Teknik pengumpulan data adalah dengan posttest dalam bentuk pengisian jawaban singkat dan pernyataan dengan 10 item, sedangkan untuk teknik tanggung jawab siswa, menggunakan teknik kuesioner. Data yang telah diperoleh kemudian dianalisis untuk menguji hipotesis dengan menggunakan rumus uji t. Berdasarkan hasil penelitian, ditemukan bahwa penerapan model pembelajaran tipe VCT mempengaruhi pada prestasi belajar untuk siswa kelas empat SD N 1 Tinggarjaya dalam Mata Pelajaran Pendidikan Kewarganegaraan pada topik Globalisasi.

Kata Kunci: Value Clarification Technique (VCT), tipe contoh, prestasi belajar, Pendidikan Kewarganegaraan, Globalisasi.

\section{PENDAHULUAN}

Pendidikan nasional yang berdasarkan Pancasila dan Undang-Undang Dasar Negara Republik Indonesia Tahun 1945 berfungsi mengembangkan kemampuan dan membentuk watak serta peradaban bangsa yang bermartabat dalam rangka mencerdaskan kehidupan bangsa serta mengembangkan potensi siswa agar menjadi manusia yang beriman dan bertakwa kepada Tuhan Yang Maha Esa, berakhlak mulia, sehat, berilmu, cakap, kreatif, mandiri, dan menjadi warga negara yang demokratis serta bertanggung jawab. Sekolah sebagai salah satu sarana pendidikan formal, melalui kurikulumnya bertugas untuk mencapai fungsi tersebut semaksimal mungkin. Salah satu mata pelajaran yang diajarkan di sekolah yaitu Pendidikan Kewarganegaraan (PKn), tujuan 
konkrit mata pelajaran PKn adalah menyiapkan dan mengarahkan siswa untuk menjadi masyarakat madani, yaitu sebuah sistem sosial yang menjunjung tinggi prinsip moral.

Upaya penanaman nilai (value), sikap, penghayatan, citra, cita rasa, emosi serta perasaan kepada siswa sebagai wujud domain afektif yang merupakan dasar dari pembentukan karakter dan kepribadian bangsa harus dilakukan dengan cara yang tepat. Tugas PKn untuk membentuk warga negara menjadi masyarakat madani tentu diperlukan sebuah strategi dan pendekatan pembelajaran khusus yang sesuai dengan tujuan konkrit mata pelajaran PKn. Pembelajaran PKn ditujukan secara jelas untuk pembentukan sikap serta melatih berbagai keterampilan yang sesuai dengan materi pembelajaran serta suasana pembelajaran.

Sanjaya (2010: 283) mengungkapkan bahwa teknik mengklarifikasi nilai (Value Clarification Technique) atau yang sering disingkat VCT dapat diartikan sebagai teknik pengajaran untuk membantu siswa dalam mencari dan menentukan suatu nilai yang dianggap baik dalam menghadapi suatu persoalan melalui proses menganalisa nilai yang sudah ada dan tertanam dalam diri siswa. Model pembelajaran ini merupakan model pembelajaran yang berorientasi penanaman nilai dan menjadi awal untuk pembentukan sikap karena pada proses pembelajarannya siswa dibina kesadaran emosional nilainya melalui cara yang kritis dan emosional untuk mengklarifikasi dan menguji kebenaran/ kebaikan/ keadilan/ kelayakan/ ketepatannya. Langkah-langkah model pembelajaran VCT sejalan dengan tujuan pembelajaran mata pelajaran $\mathrm{PKn}$ dan di dalam model pembelajaran VCT ini terdapat berbagai macam tipe antara lain tipe percontohan, tipe analisa nilai, tipe daftar/matrik, tipe kartu keyakinan, teknik wawancara/ interview, teknik yurisprudensi, teknik inkuiri nilai dengan pertayaan acak.

Tipe dalam model pembelajaran VCT yang dipakai oleh peneliti yaitu tipe percontohan, tipe percontohan ini menggunakan cerita yang didramatisir agar siswa dapat ikut merasakan konflik yang ada di dalam cerita. Tema cerita yang disajikan sebisa mungkin sesuai dengan lingkungan di sekitar siswa agar siswa lebih merasa terlibat di dalam konflik cerita. Melalui cerita tersebut diharapkan guru dapat menggali nilai-nilai dan perasaan dalam diri siswa melalui kegiatan berdiskusi. Kegiatan diskusi disini memberikan kesempatan kepada siswa untuk melatih keterampilan dalam berdiskusi. Setelah diketahui nilai-nilai yang ada dalam diri siswa, guru bersama siswa bersama-sama mengklarifikasi dan membuktikan nilai-nilai tersebut. Tahap akhir dari tipe percontohan ini yaitu membuat kesimpulan dari materi atau konsep yang sedang dipelajari serta menentukan tindakan apa yang seharusnya dilakukan sesuai dengan nilai- nilai yang terkandung dalam konsep atau materi tersebut. Melalui metode VCT tersebut, guru juga dapat menekankan keberhasilan aspek kognitif melalui penyajian cerita yang mengandung materi pelajaran yang akan dipelajari, dimana isi cerita tersebut disesuaikan dengan kejadian-kejadian pada lingkungan sekitar siswa/sehingga peseta didik lebih mudah memahami materi yang diajarkan dan pembelajaran akan lebih bermakna karena siswa tidak merasa asing dengan materi yang sedang dipelajari.

Berdasarkan latar belakang masalah di atas, maka penelitian ini penting dilakukan guna mengetahui "Pengaruh Model Pembelajaran Value Clarification Technique (VCT) Tipe Percontohan Terhadap Prestasi Belajar dan Tanggung 
Jawab Siswa Kelas IV SD N 1 Tinggarjaya Materi Globalisasi Mata Pelajaran PKn”.

\section{METODE PENELITIAN}

Pelaksanaan penelitian ini menggunakan metode eksperimen dengan desain penelitian Randomized Control Group Pre tes -Post test Design, dalam desain ini, pengambian sampel penelitian dilakukan secara acak. Populasi dalam penelitian ini adalah seluruh siswa kelas IV yang terdiri dari dua kelas yaitu kelas IVA dan IVB SD $\mathrm{N} \quad 1$ Tinggajaya yang berjumlah 65 . Sampel yang dijadikan kelas eksperimen adalah kelas IVB sedangkan kelas IVA dijadikan sebagai kelas kontrol. Kelas eksperimen dan kelas kontrol akan diberi perlakuan berupa pemberian model pembelajaran yang berbeda. Kedua kelas ini akan diberi pre tes dan pos tes untuk megetahui pengaruh dari perlakuan yang diberikan.

Instrumen pengambilan data untuk prestasi belajar siswa yaitu menggunakan tes yang disajikan dalam bentuk isian singkat dan uraian, sedangkan untuk pengambilan data tanggung jawab siswa menggunakan angket. Metode untuk menganalisis data yang telah diperoleh menggunakan uji hipotesis rumus uji t, sebelum uji hipotesis menggunakan rumus uji $\mathrm{t}$ dilakukan maka terlebih dahulu dilakukan uji prasyarat yaitu uji normalitas dan uji homogenitas.

\section{HASIL PENELITIAN DAN PEMBAHASAN \\ Prestasi Belajar Siswa Mata Pelajara PKn}

Hasil penelitian menunjukkan adanya pengaruh penerapan model pembelajaran Value Clarificatin Technique (VCT) di kelas eksperimen terhadap prestasi belajar siswa kelas IV SD N 1 Tinggarjaya, hal ini dibuktikan dengan uji hipotesis menggunakan uji t secara manual maupun pengujian menggunakan SPSS. Perolehan hasil uji $t$ secara manual menunjukkan bahwa $t_{\text {hitung }}>t_{\text {tabel }}$ atau 3,28 > 1,658 yang berarti Ho ditolak dan $\mathrm{Ha}$ diterima. Hal ini diperkuat dengan hasil perhitungan menggunakan SPSS dimana nilai signifikasi sebesar 0,003 ; signifikansi $0,003<0,05$ sehingga Ho ditolak dan $\mathrm{Ha}$ diterima. hasil perhitungan manual dan SPSS secara lebih jelas dapat dilihat pada tabel berikut :

Tabel 1.

Hasil Perhitungan Hasil Belajar Aspek Kognitif Manual dan SPSS

\begin{tabular}{|l|l|l|}
\hline Uji t (manual) & $3,28>1,658$ & Ho ditolak, Ha diterima \\
\hline SPSS & $0,003<0,05$ & Ho ditolak, Ha diterima \\
\hline
\end{tabular}

Pengaruh model pembelajaran Value Clarification Technique atau VCT ini terlihat dari perbedaan nilai rata-rata pos tes antara kelas eksperimen dan kelas kontrol. Nilai rata-rata pos tes untuk kelas eksperimen sebesar 85,7 sedangkan nilai rata-rata pos tes kelas kontrol sebesar 78,375 . Perbedaan nilai yang signifikan ini menunjukkan bahwa siswa di kelas eksperimen yang mengikuti pembelajaran menggunakan model pembelajaran VCT pada materi globalisasi lebih tinggi daripada siswa di kelas kontrol yang mengikuti pembelajaran menggunakan model pembelajaran langsung.

Pengaruh model Value Clarification Technique (VCT) tipe percontohan di kelas eksperimen terhadap aspek kognitif siswa 
dikarenakan proses pembelajaran yang dilakukan selalu dikaitkan dengan kehidupan nyata siswa, hal ini membuat pembelajaran menjadi lebih mudah dimengerti dan berkesan bagi siswa karena menyangkut pengalaman pribadi atau kondisi di lingkungan sekitarnya. Penyajian materi pembelajaran yang dikemas dalam bentuk cerita fiktif, namun tema cerita tersebut merupakan hal yang sering terjadi di lingkungan siswa membuat siswa lebih tertarik terhadap pembelajaran yang sedang berlangsung. Hal ini tentu saja berpengaruh terhadap daya tangkap materi siswa dalam pembelajaran. Hal ini sependapat dengan Nandari, dkk (2013) dalam jurnalnya bahwa model pembelajaran VCT bermuatan cerita berdilema moral lebih mudah dalam menangkap materi mengenai globalisasi karena berkaitan erat dengan situasi kehidupan sehari-hari yang dihadirkan melalui cerita berdilema moral. Melalui cerita berdilema moral siswa mengkaji berbagai isu-isu sosial yang terjadi di

Tabel 2. Hasil Perhitungan Hasil Belajar Aspek Afektif Manual dan SPSS

\begin{tabular}{|l|l|l|}
\hline Uji t (manual) & $2,16>1,658$ & Ho ditolak, Ha diterima \\
\hline SPSS & $0,001<0,05$ & Ho ditolak, Ha diterima \\
\hline
\end{tabular}

Adanya pengaruh model Value Clarification Technique (VCT) tipe percontohan terhadap tanggung jawab siswa terbukti dengan perbedaan rata-rata skor angket antara kelas eksperimen dan kelas kontrol. Rata-rata skor angket kelas eksperimen sebesar 33,41 sedangkan ratarata skor angket kelas kontrol sebesar 31,125 . Perbedaan yang signifikan tersebut menunjukkan bahwa penerapan model Value Clarification Technique (VCT) tipe percontohan berpengaruh lebih baik terhadap tanggung jawab siswa kelas IV di kelas eksperimen berpengaruh lebih baik dibandingkan dengan penerapan model pembelajaran langsung di kelas kontrol terhadap hasil belajar aspek afektif siswa. rumah, sekolah, dan masyarakat yang nantinya berguna bagi kehidupannya seharihari.

\section{Tanggung Jawab Siswa}

Hasil penelitian menunjukkan adanya pengaruh penerapan model pembelajaran Value Clarificatin Technique (VCT) di kelas eksperimen terhadap tanggung jawab siswa kelas IV di SD N 1 Tinggarjaya, hal ini dibuktikan dengan uji hipotesis menggunakan uji t secara manual maupun pengujian menggunakan SPSS. Perolehan hasil uji $t$ secara manual menunjukkan bahwa $t_{\text {hitung }}>t_{\text {tabel }}$ atau 2,16> 1,658 yang berarti Ho ditolak dan $\mathrm{Ha}$ diterima. Hal ini diperkuat dengan hasil perhitungan menggunakan SPSS dimana nilai signifikasi sebesar 0,000 ; signifikansi $0,001<0,05$ sehingga Ho ditolak dan $\mathrm{Ha}$ diterima. hasil perhitungan manual dan SPSS secara lebih jelas dapat dilihat pada tabel 2. 
siswa perempuan dengan temannya, dia mengatakan kepada temannya bahwa "Kalau aku jadi Aji, aku tetap tampil di Jepang, karena aku jadi wakilnya Indonesia". Berdasarkan isi pembicaraan salah seorang siswa tersebut dapat ditarik kesimpulan bahwa cerita VCT mampu menggali nilai yang terdapat dalam diri siswa,nilai tersebut adalah nilai tanggung jawab karena inti dari isi percakapan tersebut yaitu dia memilih menunaikan tugasnya daripada mementingkan haknya. Setelah nilai yang diharapkan ada dalam diri peseta didik muncul, maka guru harus mampu mengklarifikasi kebenaran nilai tersebut dan mengarahkan agar siswa dapat menerapkannya dalam kehidupan seharihari. Hal ini sesuai dengan pendapat Djahiri (Wiratama: 2013) mengenai kelebihan model pembelajaran VCT, salah satunya yaitu membina kepekaan afektual siswa akan esensi berbagai nilai moral yang perlu dibina, ditegakkan dan dilestarikan serta didorong untuk menganut, meyakini dan menampilkannya (moral performance) sebagai tampilan diri dan kehidupannya.

\section{SIMPULAN DAN SARAN}

Berdasarkan hasil analisis data menggunakan teknik manual dengan rumus uji $\mathrm{t}$ diperoleh data prestasi belajar siswa yaitu $t_{\text {hitung }}>t_{\text {tabel }}$ atau 3,28 $>1,658$, dan tanggung jawab siswa yaitu $t_{\text {hitung }}>t_{\text {tabel }}$ atau 2,16>1,658. Simpulan dari hasil perhitungan di atas yaitu terdapat pengaruh model pembelajaran Value Clarification Technique (VCT) terhadap prestasi dan tanggung jawab siswa kelas IV SD N 1 Tinggarjaya materi globalisasi mata pelajaran PKn.

Melalui hasil penelitian yang telah dilakukan oleh peneliti dan simpulan yang didapat, maka terdapat beberapa saran untuk perbaikan proses belajar mengajar menggunakan model VCT, antara lain yaitu: proses pembelajaran menggunakan model VCT memerlukan keterampilan bertanya bagi guru, agar siswa selalu terpancing untuk mengutarakan (mengemukakan) nilai-nilai yang terdapat di dalam dirinya secara terbuka.. Cerita berdilema moral yang disajikan sebagai sarana penyampaian materi harus dibuat benar yaitu dapat sejalan dengan tujuan pembelajaran yang akan dicapai, menarik yaitu agar siswa tertarik untuk mengungkapkan nilai yang ada di dalam diriya secara terbuka dan lengkap yang berarti isi cerita mencakup materi pembelajaran yang akan diajarkan. Tema cerita juga diusahakan sesuai dengan kejadian yang sering muncul di lingkungan siswa. Guru harus selalu aktif untuk melibatkan siswa dalam dialog terpimpin agar guru dapat memahami dan menggali nilai-nilai yang terdapat dalam individu masing-masing

\section{DAFTAR PUSTAKA}

Nandari, Ida Ayu Tri dkk. (2013). "Pengaruh Model Pembelajaran VCT Bermuatan Cerita Berdilema Moral Terhadap Hasil Belajar Pendidikan Kewarganegaraan Siswa Kelas IV SD Negeri 1 Kamasan". Mimbar PGSD Vol.1 Tahun 2013.

[Online]. Tersedia

http://ejournal.undiksha.ac.id/index. php/JJPGSD/article/view/1385

Sanjaya, Wina. (2010). Strategi Pembelajaran Berorientasi Standar Pendidikan. Jakarta : Kencana.

Sudjana, Nana. (2011). Penilaian Hasil Proses Belajar Mengajar. Bandung : PT. Remaja Rosdakarya.

Wiratama, Gd. Arya dkk. (2013). "Pengaruh Model Pembelajaran 


\section{Desty Ratna Permatasari}

VCT Berbantuan Media Cerita

Bergambar Terhadap Hasil Belajar

Ranah Afektif Siswa Mata

Pelajaran Pkn Kelas IV SD".

Mimbar PGSD Vol.1 Tahun 2013.

[Online].

Tersedia

http://ejournal.undiksha.ac.id/index.

php/JJPGSD/article/view/832 